\title{
Geomorphometric and Terrain Analysis of the Nigerian Section of the Chad Basin (Bornu Basin) Northeastern Nigeria
}

\author{
Yakubu Mohammed ${ }^{1}$, Ibrahim B. Wulo ${ }^{1}$, John Abdullahi², Aishe K. Gazali ${ }^{1}$, Zanna A. Lawan ${ }^{3}$ \\ \& Hamman I. Kamale ${ }^{1}$ \\ ${ }^{1}$ Department of Geology, Faculty of Science, University of Maiduguri, Borno State, Nigeria \\ ${ }^{2}$ Department of Geography, Faculty of Social Sciences, University of Maiduguri, Borno State, Nigeria \\ ${ }^{3}$ Chad Basin National Park, Maiduguri, Borno state, Nigeria \\ Correspondence: Yakubu Mohammed, Department of Geology, Faculty of Science, University of Maiduguri, \\ P.M.B 1069, Borno State, Nigeria. E-mail: yakubu.mohammed94@yahoo.com
}

Received: August 18, 2019

Accepted: September 27, 2019 Online Published: November 30, 2019

doi:10.5539/jgg.v11n4p1

URL: http://dx.doi.org/10.5539/jgg.v11n4p1

\begin{abstract}
The aim of this paper is to characterize the geomorphology and analyze the terrain of the Bornu basin. This is critical to the understanding of the general landscape configuration, its evolution and morphodynamics in the basin. Mapping was carried using the Shuttle Radar Topographic Mission (SRTM) and Digital Elevation Model (DEM) data of the area. These set of data compliments the data generated from an extensive and detailed mapping of the area adopting the holistic approach geomorphologic field mapping technique. The basins slope generated from DEM of the area indicated five terrain categories. The western end of the basin has the highest slope of 755 to $1582 \mathrm{~m}$ denoting the margins of the Biu and Jos plateau which slopes down to the lowest slope category of $256 \mathrm{~m}$ at the shores of Lake Chad. These slope categories exhibits a variety of land forms ranging from rills, gullies, ponds, rivers, deltas, alluvial plains, ridges, hills and sand dunes of variable sizes, shapes and morphological characteristics. The Bama ridge which rises to height of $363 \mathrm{~m}$ covering a distance of about 340 $\mathrm{Km}$ is a major land form in the basin. These land forms and others identified have been formed and are being fashioned by interplay of fluvial and Aeolian processes whose linkages are found to vary both in spatial and temporal dimensions.
\end{abstract}

Keywords: Geomorphology, Geomorphometric, Terrain Analysis, Morphodynamics, Chad Basin

\section{Introduction}

Geomorphology is the study of land forms and landscapes including the origin, description, clarification, development and history of planetary surface (Pereta \& Pereta, 2015). Geomorphological and terrain analysis of an environment using remote sensing technology, geographic information system global positioning system and detailed field mapping can provide information about the landscapes evolution and development, shape and dimension, surface processes and the behavior of surface drainage networks. The need for the terrain analysis of an area for environmental monitoring, planning and sustainability cannot be over emphasized. According to Mayomi, Wannah and Mbaya (2016) a proper understanding of the terrain characteristics is essential for any scientific pursuit. Remote sensing data enable direct observation of land surfaces at repetitive intervals and thus allow mapping of a large extent of land surfaces. Landsat Thematic Mapper (TM) with seven spectral bands has been effectively used for geomorphic mapping at local and regional levels (Pour \& Hashim, 2015). Utilization of Landsat false color composite images in identifying geomorphological expressions and regional structural features have been of great importance considering the fact that has sparse vegetation. The Shuttle Rader Topography Mission (SRTM) data have been utilized in digital elevation model data applications in the fields of geomorphology, geology, volcanology, hydrology, and other earth science related fields (Pan et al., 2013; Pereta \& Pereta, 2015). SRTM date are unique owing to the fact that the vast majority of the earth's surface been mapped with a single consistent method within a short period of time. Deployment of this data in this study enabled the identification of some major features which hitherto have not been clearly revealed.

Detailed geomorphic and terrain analysis of the basin provides an exact and measurable picture of the relief form and land forms which are essential in the search for solid minerals, underground water, and oil and gas. In this 
paper, the geomorphometric and terrain of the Nigerian section of the Chad basin (Bornu basin) was analyzed using information extracted and processed from the SRTM-DEM data, Landsat imagery, extensive field mapping and the review of previous literatures.

\section{The Study Area}

Nigerian section of the Chad Basin, known locally as the Bornu Basin forms the south western part of the Chad Basin in Nigeria and covers a landmass of about 2,335000Sq Km. It is one of Nigerian's inland basins occupying the northeastern part of the country and representing about one-tenth of the total area extent of the Chad Basin. The Basin is a large regional structural depression cutting across Cameroon, Central African Republic, Niger, Chad and Nigeria (Obaje, 2009). The Bornu Basin falls between latitudes $10^{\circ} \mathrm{N}$ and $15^{\circ} \mathrm{N}$ and longitudes $8^{\circ} \mathrm{E}$ and $14^{\circ} \mathrm{E}$ covering parts of Borno, Yobe and Jigawa States of Nigeria (Figure 1).

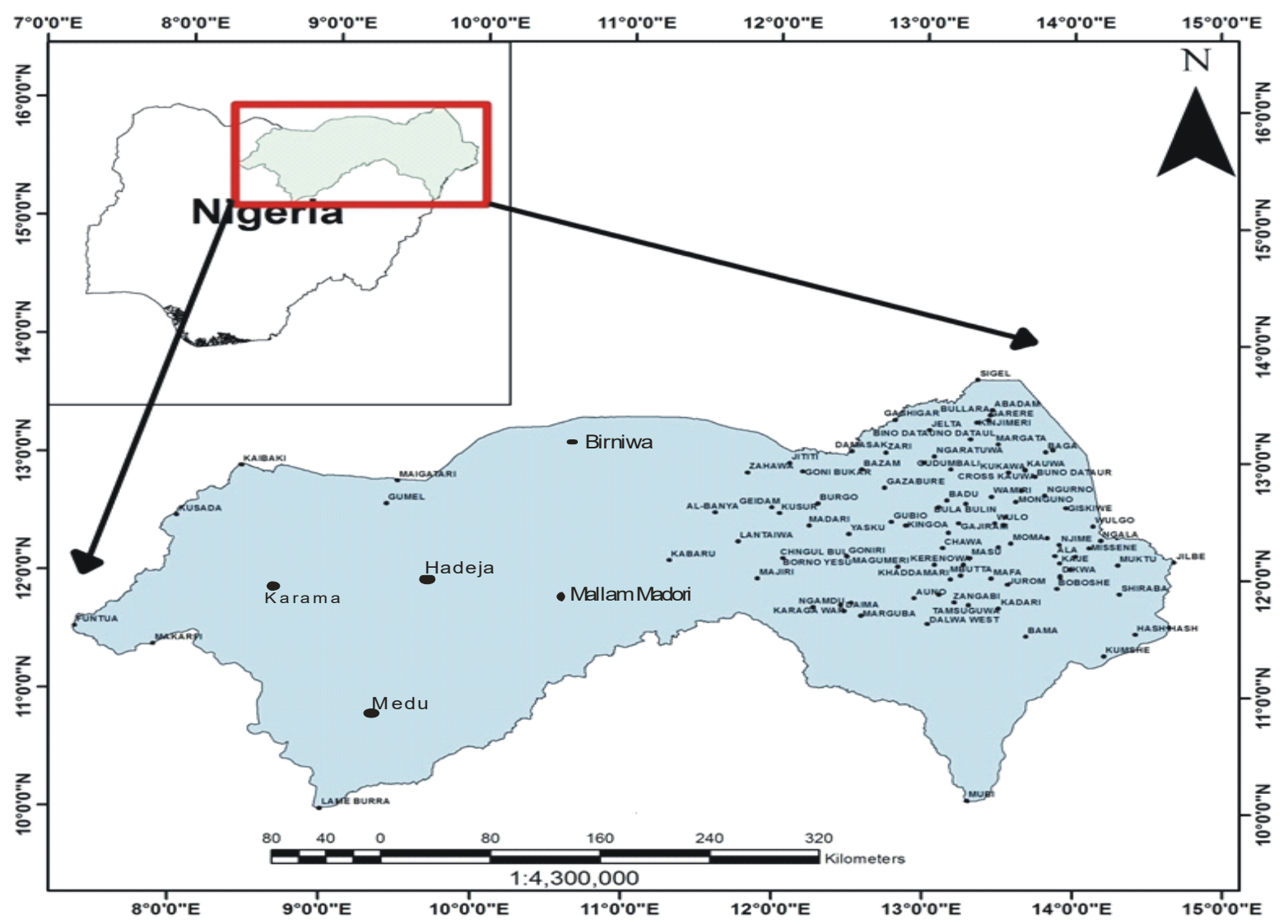

Figure 1. The Bornu Basin with some Sampling Locations

\subsection{Structural Evolution and Geologic Setting of the Basin}

It is believed that the Precambrian block of Africa was once united with the other southern continents of the globe in one great landmass called Gondwanaland which was later disintegrated by continental drift (Ofomata, 2009). According to King (1967), since the final dismemberment of Gondwanaland in the early Cretaceous period, and the birth of Africa, earth movements have continued to affect the continent. In Nigeria, apart from the fold belt of the northwest and the south, these movements have been of an epirogenic in nature, except the coastal margins which is principally of uplift. Unequal uplift and differential faulting have between them produced some of the major features of the present-day Africa (Ofomota, 2009). The interior of the continent of Africa is characterized by the existence of series of great basins, separated by gently rising uplands or plateaus. According to Ofomota (2009) the Chad basin and the sub-basin (Bornu) is an example of such structures formed during the Quaternary due to down warping. He opined that the Bornu basin is believed to represent areas which was lagged behind in the general uplift of the interior, and have become the depositing environment of eroded sediments which were eroded from the surrounding rises. Less (1982) and Carter et al., (1963) explained that the 
basin originated as part of the Benue Trough being an extension of the third and failed arm of a triple rift junction system which opened as a subsidiary basin to the emerging Atlantic Ocean during the late Jurassic to early Cretaceous.

Furon (1963) suggested that the Chad Basin represents the place of dissection of tectonic troughs while Peters and Ekweozor (1982) was of the opinion that the basin resulted from seafloor spreading along the continental margins of West Africa. Peters further argued that its differentiation in to sub-basins was controlled by rifting and subsidence developing into major grabens. It is evident from the position of researchers that the evolution of the basin is complex. However, one key important point to note is that the Bornu basin is genetically linked with the Benue Trough and showed evidence of a rift origin without any strong indication of being fault bounded. The basin is bounded by the Biu plateau region occurring in the southern part, with the Jos plateau flanking the western edge while the eastern margin is bounded by the Mandara Mountains (Figure 2).

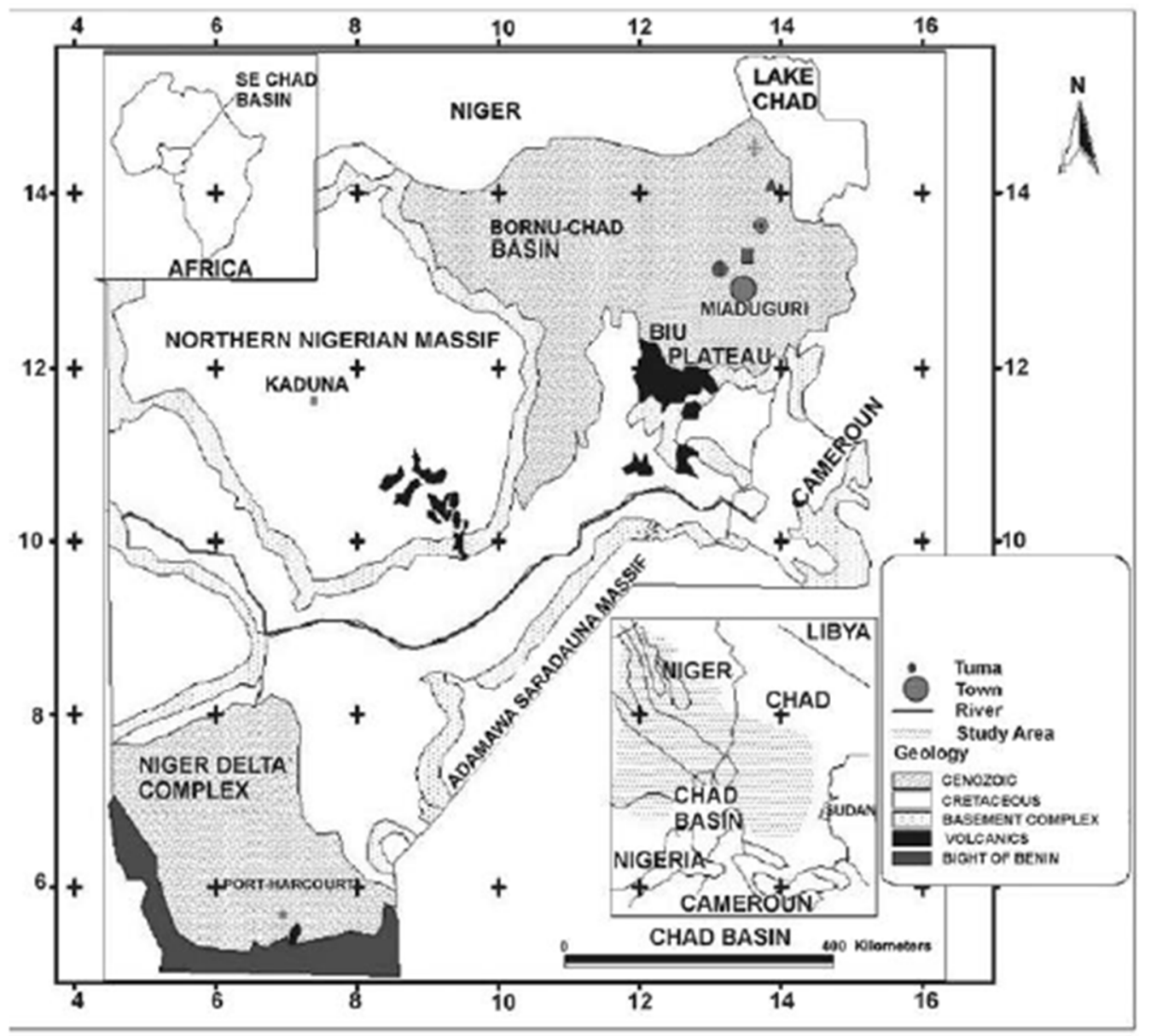

Figure 2. The location of Bornu Basin in Relation to other Inland basins in Nigeria (Giraud, 1990)

As stated earlier, the Bornu basin is an intra-continental Cretaceous to Holocene rift basin located in northeast Nigeria. The oldest rocks in the basin consist of Precambrian to Lower Paleozoic Migmatites and Granite followed by the lacustrine and terrestrial deposits of the Bima sandstone Formation. According to Avbovbo et al., (1986) and Samaila et al., (2006), this deposit is the oldest sedimentary strata corresponding to the Lower Cretaceous (Albian to Cenomanian). The Bima sandstone is overlain by the estuarine marine deposits of the Gongila Formation (Cenomanian to Toronian), which is also overlain by the marine Fika shale deposited during a major transgression in the Turonian to Campanian period (Carter et al., 1963). The estuarine to deltaic clastics of the Gombe sandstone (Mastrichian), overlie the Fika shale while the non-marine Kerri-kerri Formation (Paleogene) was unconformably deposited unto the Gombe sandstone across most of the basin (Obaje, 2009). The Quaternary Chad Formation is the youngest rock in the basin, largely consisting of lacustrine and alluvial sedimentary strata. Figure 3 is the Stratigraphy of the Bornu basin. 


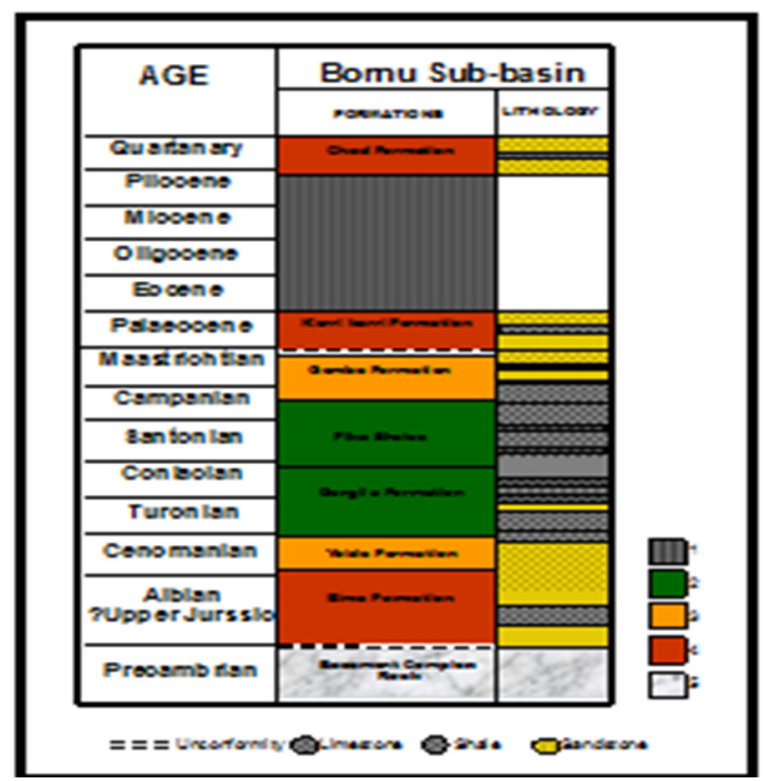

Figure 3. Stratigraphy of the Bornu basin (Carter et al., 1963)

\section{Materials and Methods}

In this research, the Shuttle Radar Topographic Mission (SRTM), Digital Elevation Model (DEM) and data generated from the detailed field mapping were utilized. The Shuttle Radar Topographic Mission (SRTM) image of the area with a spatial resolution of $90 \mathrm{~m}$ was acquired through the Geological Survey Earth Resources Observation and Science Centre (EROS). This was used in generating the DEM of the area trough DEM creation module of the ArcGIS software. The generated (DEM) of the area was utilized for the generation of contour, slope, aspect and the 3D map of the area. ArcGis 10.1 (ArcMap 10.1) software was employed in the spatial analysis of these geomorphic variables. Finally, an extensive field mapping was carried out adopting the holistic approach geomorphological field mapping technique. Through this, different land forms were identified in the field and studied in detail. Measurements were carried out and details of attributes recorded and compared with standard references for proper description.

\subsection{Morphodynamics and Landscape Development in the Basin}

Landscape evolution in the basin is obviously shaped by low annual precipitation, sparse vegetation, characteristic ephemeral (seasonal) erosion and depositional processes. Landscape in the basin is fashioned by the interplay of fluvial and aeolian processes. The fluvial processes which takes place during the short rainy season (July to September) whiles the aeolian processes predominates during the long dry season from October to May. The availability of water or otherwise controls the degree to which fluvial or aeolian processes influence sediment transport in geomorphic environments (Belnap, Munsun and Field. 2011). Aeolian processes dominates transport when water availability is low and decrease in importance as water availability increases, while fluvial processes become increasingly prominent as water availability increases. The key factor here is that wind and water have the greatest overlap and potential for elevated sediment detachment and transport in the basin.

The sequence of events for both wind and water erosion is similar (Visser et al., 2004). First the sediments are dislodged by either of the two and subjected to transport. The entrained particles are transported until the transporting agent (wind or water) velocity decreases and gravitational force causes the particles to settle out according to size and weight. Most of the observed streams in the basin are ephemeral which flow only during storm events, perhaps flowing several hours to days in a year. Rain splash, sheet wash, riling and flash flooding are the dominant fluvial erosion processes in the basin. Deflation, blow outs and sand blasting are the major aeolian erosion process in the basin. The scanty vegetation cover coupled with the sporadic and intense nature of precipitation over the basin results to great volumes of sediments released in a relatively short period of time. The inter-annual sand storm also transports and deposits huge amount of sediments on the basins floor (Figure 5).

Most of the drainage basins tend to be closed with internal drainage and basin sedimentation which become 
rapidly choked up with sediments during concentrated flood events. Despite the overall year round precipitation in the area being low, its intense and instantaneous accumulation rates due to heavy storm downfall results to flash floods. As a result, water is the dominant agent of erosion not wind as one might expect. Deposition of eroded sediments in the basin is highly restricted due to the relatively flat and closed nature of the drainage systems. This is with the exception of the drainage systems which include the Hadejia/Jama'are-Kamodugu/Yobe and the Yadzaram-Ngadda river systems. These drainage systems tend to move huge sediments down slope to the plains of Lake Chad. This conforms to the west-east sloping nature of the basin as indicated in Figure 4. Field observation of the physical characteristics of recent fluvial deposits indicates that the sediments down slope approaching the lake are finer, well rounded and quartz dominated. This is an indication that these sediments are being extensively reworked as they move down slope. The main intervening factor between the two forces or agents of erosion is this type of basins is the topographic nature (Belnap, Munson and Field 2011). According to the authors, topography apart from being the driver of water and wind erosion, it is also being influenced by the two processes. In the case of the basin under study, aeolian activities enhance the topographic relief while the fluvial activity levels it. Sediments transported by one agent of erosion can become the material available for transport by the other agents of erosion. Sediments transported and deposited by wind (Figure 5A and B) can be washed and subjected to fluvial transport. This makes one to conclude that aeolian and fluvial processes and their linkages vary in both spatial and temporal dimension in the basin.

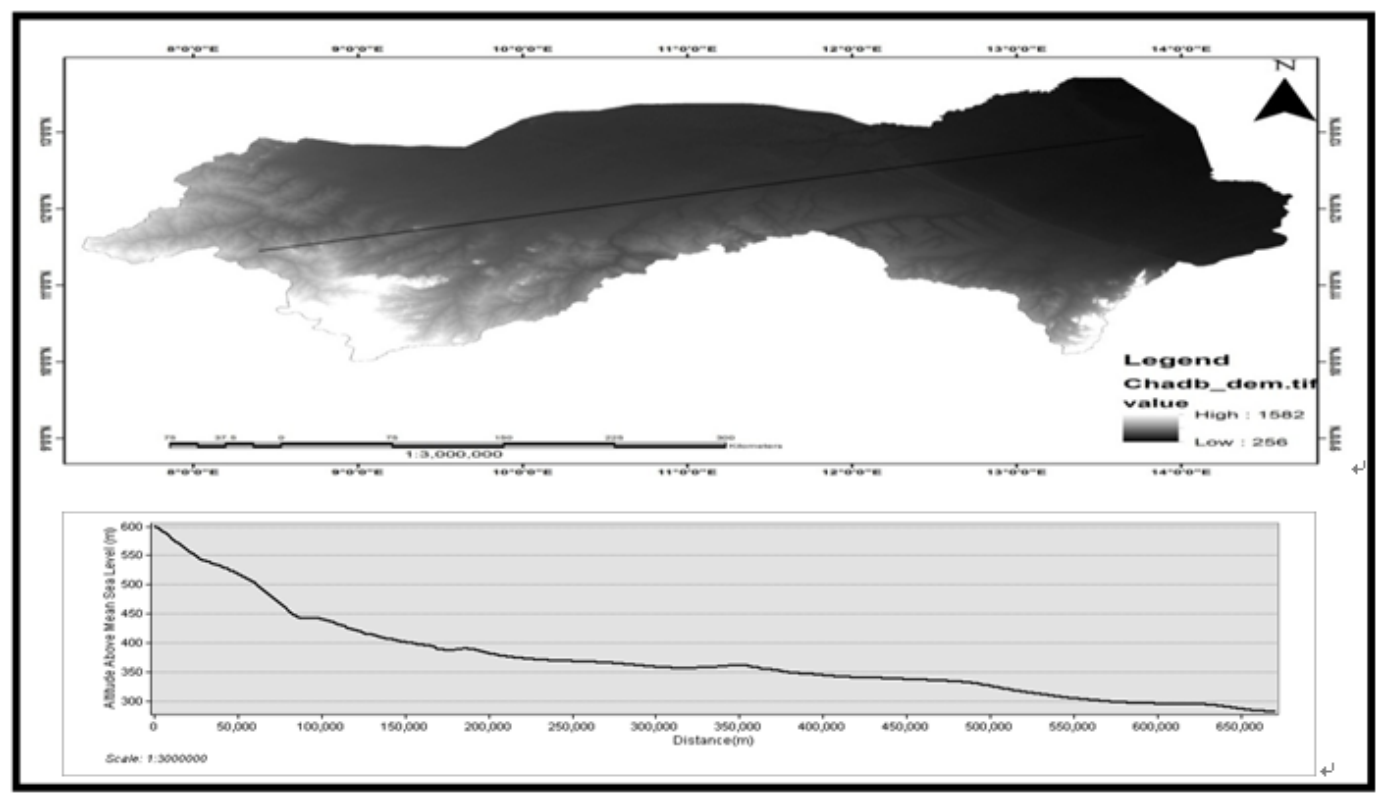

Figure 4. Aspect map of the basin with a west to east profile
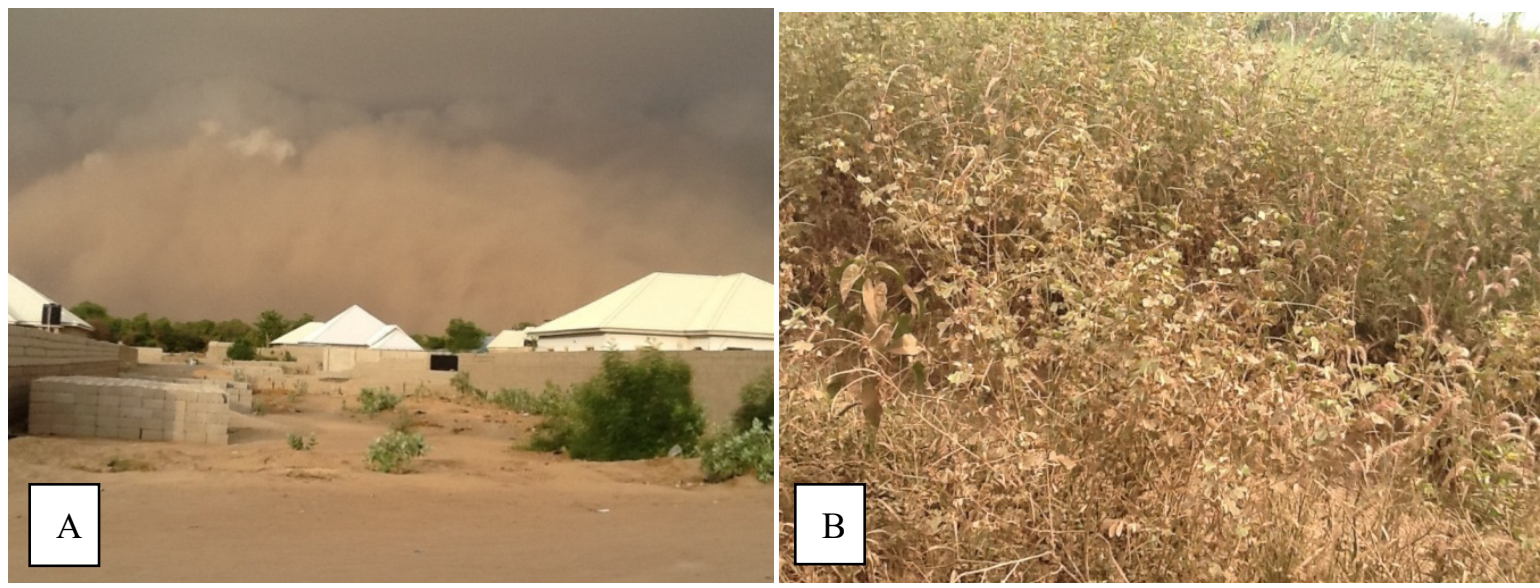

Figure 5. (A) Sand storm in Maiduguri (B) Sediments deposited after the storm on a vegetation cover in the same environment 


\subsection{Relief, Landforms and the Morphology of the Basin}

The relief, shape and morphology of the basin is presented in Figure (6A \& B). The relief's morphology is controlled by the interrelationships between the relief, the land forms and the underlying rock formations. The relief as it exist currently is the product of more than one geomorphic process or cycle. This is exemplified by the diverse nature of physiographic expressions of the basin. The slope and the 3D map (Figure 6 A \& B)

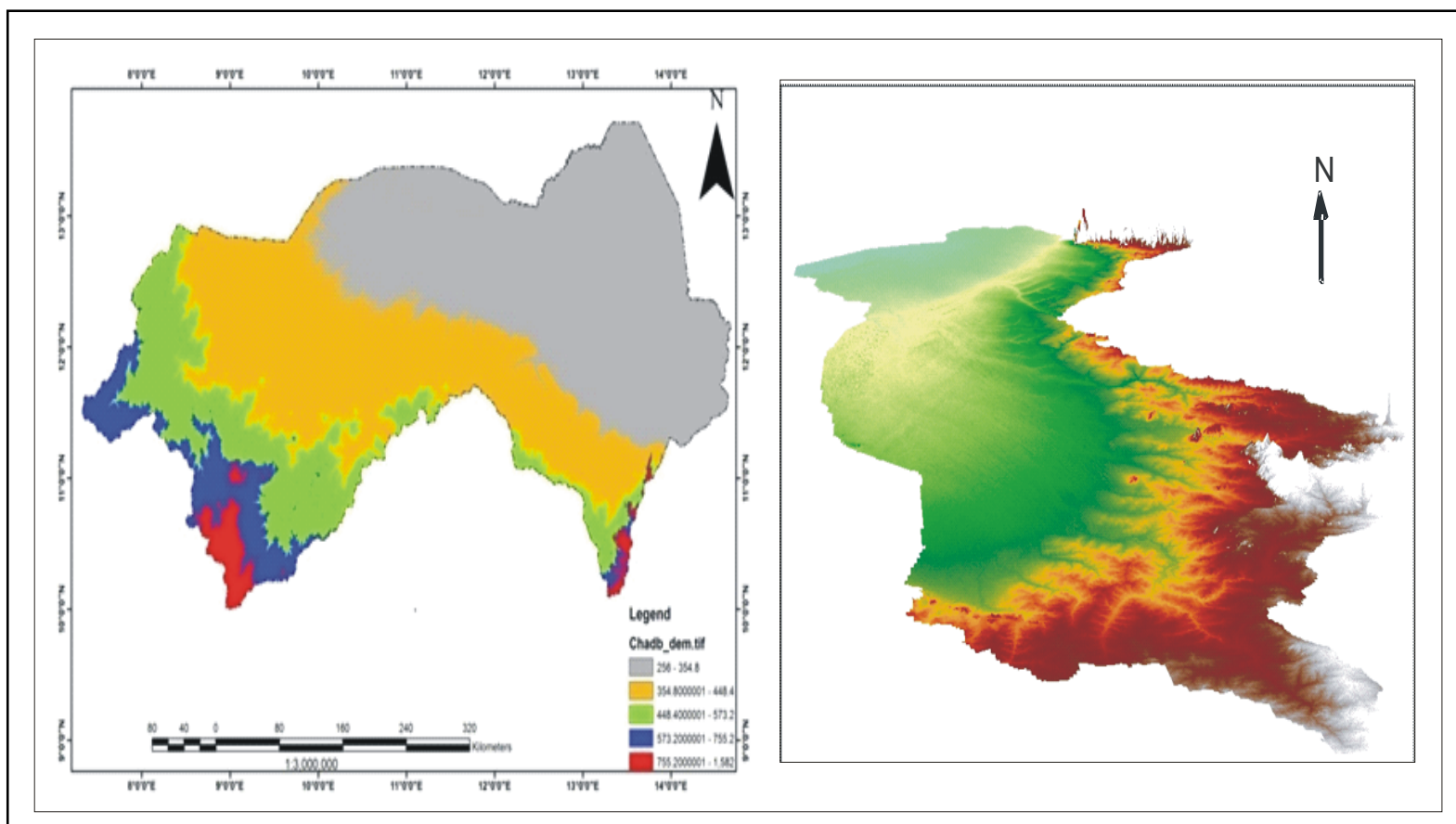

generated from the DEM of the basin indicate five terrain classes or categories as well as their heights.

Figure 6. (A) The Slope of the Basin and (B) The 3D view of the Basin

The eastern part of the basin consists of a terrain almost entirely of extensive flat or very gently undulating plains ranging from 256 to $354 \mathrm{~m}$ which runs down to the shores of Lake Chad. This terrain is separated by a complex sand ridge popularly referred to as the Bama ridge. The ridge which rises to about $360 \mathrm{~m}$ above sea level and $40 \mathrm{~m}$ above the surrounding and runs in a northwest-southeast direction over a distance of about $340 \mathrm{Km}$ separates this zone and that of the middle zone of the basin. The centre of the basin is marked by a relief that has a relatively higher elevation of 354 to $448 \mathrm{~m}$. This zone is encompassing of extensive ancient river courses, deltas and alluvial planes which had been extensively reworked by wind action. Also, sand dunes and series of aeolian sand plains abound this zone. Further west of Figure (2A), the terrains elevation is ranged between 448 to $573 \mathrm{~m}$. In this terrain category, the dune fields merges with the drift sand plains which overlie the Kerri-Kerri formation which in some places have been extensively incised by erosion forming flat topped hills with ion stone capping. Towards the northwestern part of this zone, a pattern of north-south aligned low undulations of relict dunes are quite conspicuous.

The fourth relief category with an elevation ranging between 573 to $755 \mathrm{~m}$ is made up of wide-ranging upland plains with outcrops of flat topped iron-stone capped relict hills. Here, the sand dunes are uneven both in width and spacing extending upward towards areas covered by inselbergs or rock outcrops. The Kazaure laterite ridges are very prominent in this area representing the high grounds with elevation of up to $30 \mathrm{~m}$. The ridges and sand dunes in this zone and the adjoining areas down slope appear to be made up of red sediments which are more stable, and less susceptible to erosion activities compared to the ones down slope towards the Lake Chad. This according to Nichol (1991), after the arid phases, subsequent periods of wetter periods predominate in the area. This results to the sediments making up the sand dunes being stabilized for long enough to have acquired their red staining. Also, the in-situ weathering of silicate minerals is which is quite common in a Savannah climate could have resulted to such effect (Cooke \& Warren, 1773). The extreme southwestern part of the basin forms 
the highest elevations in the basin (755 to 1582) representing the margins of the Jos and Biu plateau. In this relief zone, the plains are separated by outcrops of basement complex rock and hill ranges which in some places rises up to $1582 \mathrm{~m}$. The hills are usually capped by a thin layer of lateritic soil. The relatively undulating reliefs in this zone also consist of fossil dunes and dune ridges separated by gorges with a thin cover of alluvial sediments.

One of the prominent morphological features in the basin is the Bama ridge. The ridge was considered to have been formed during the Late Pleistocene representing the ancient shoreline of the Mega Lake Chad when it receded (Grove, 1959; Durand, 1982). The Bama ridge (BR) refers to the Nigerian portion of Mega Lake Chad paleo-beach ridge with its origin and period is marred by contradictions. Ostaficzuc (1985) opined that the ridge formed as a result of sediments accumulating along a neo-tectonic fault. According to the author, this probable fault line trending NNW-SSE guided the initial accumulation of sediments along the southwest shores of the Mega Lake Chad.

Oteze and Tamajong (1987) asserted that the BR evolved between 29,000 to 20,000 years B.P. when the Lake Chad was at its peak. This assertion is also held by Durand (1982) who strongly suggests that the Mega Lake Chad was at its terminal peak of $320 \mathrm{~m}$ a.m.s.l. at that period and logically extrapolated that the BR was established at that period. The multiple transgression phases of the Lake Chad with peak levels at $320 \mathrm{~m}$ a.m.s.l have been held by (Oteze \& Tamajong 1987; Valdery, 1980) but with contradicting time frames. Nyanganji (2002) presents numerous evidences strongly suggesting that the BR evolved during the fluvial period between 29,000 to 20,000 years B.P. Although the ridge could have formed as shore line deposits, its preferred aligning towards a certain orientation could not been a mere coincidence. The evolution of the Chad basin has resulted to tectonic faults having similar trends over hundreds and thousands of kilometers across the entire basin. This makes it apparent that a certain form of structure had played a major role in the alignment of the ridge.

From the generated contour map of the area, the Bama ridge is conspicuous and rises fairly above the surrounding environment. It has an elevation of $360 \mathrm{~m}$ with a linear morphology aligned in a north-west to south-east direction (Figure 7A \& B). It is a conspicuous landform in the vicinity of Gaidam, Gasua and Nguru in Yobe state down through Magumeri, Maiduguri, Konduga and Bama towns of Borno State spanning over a distance of about $340 \mathrm{~km}$. The ridge is best developed in thickness around Maiduguri and Bama and thins out through the northern tip of the Mandara hills in the southeastern boundary of the basin. The southwestern part of the ridge flattens out beneath the sand dunes of the northern margin of the basin.

Field observations around Maiduguri and Bama revealed that the Bama ridge comprised of a series of parallel sub-ridges separated by troughs attributable to sedimentations along the major ridge. Along the towns, the ridge is observed to be highly dissected by the Ngadda channels which also breach it. Also, a fan-shaped massive bulge is observed around Bulamari close to Bama. This bulge according to Nyanganji (2002) is assumed to be created by a deltaic depositional process as rivers Yedzaram and Gombole approaches the ridge. This assumption is valid considering the findings of Zarma (2015) that the pebbles found in ridge were shaped dominantly in a deltaic environment.

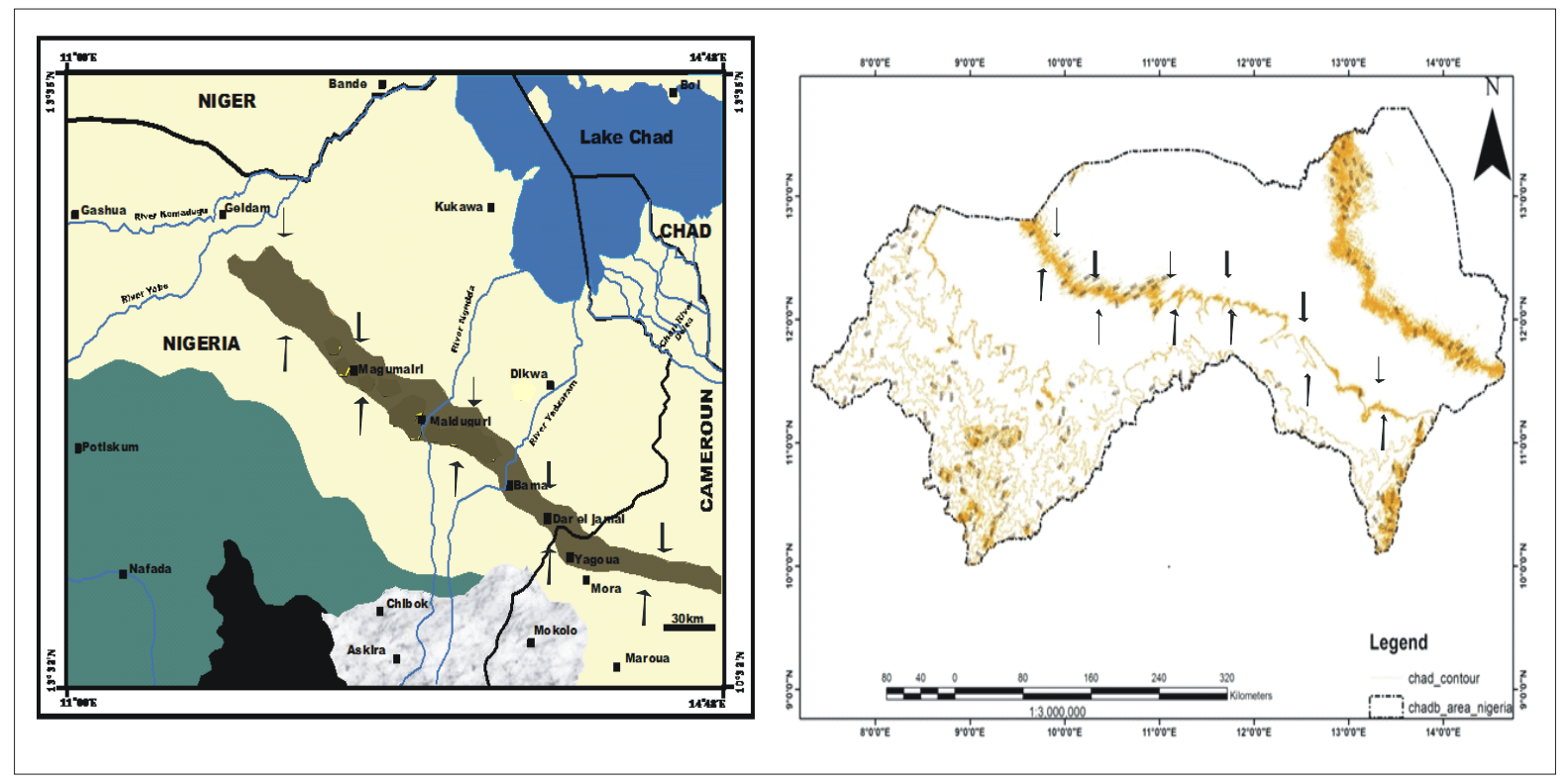


Figure 7. (A) The aerial extent of the ridge and (B) is the contour map indicating the height of the ridge: The BR pointed by arrows

On a micro-scale, rills and gullies are the common fluvial landforms along river channels and rims of depressions. These further develop to deeper depressions or lengthened stream catchment networks. This development as earlier stated starts with the development of sheet wash on slopes which combine to form rills. These advance and develop to gullies (Figure 8A) which also elongates by headword erosion into the surrounding areas, developing a tributary catchment. On the other hand, the combined sheet wash that forms rills buckled and form ponds which also further expand its bank through the former process (Figure 8B).

During the long periods of dryness, wind blowing the dry sand surface ripples the surface into crests and troughs mostly aligned to a NE-SW direction. Accumulation of additional sediments by wind on the crest of these ripples results to the formation of mould which sometimes merges and form ridges (Figure 8C). The trough's sediments are blown by winds which continue to depress it which further sets the formation of deflation basins also referred to as blow outs (Figure 8D).
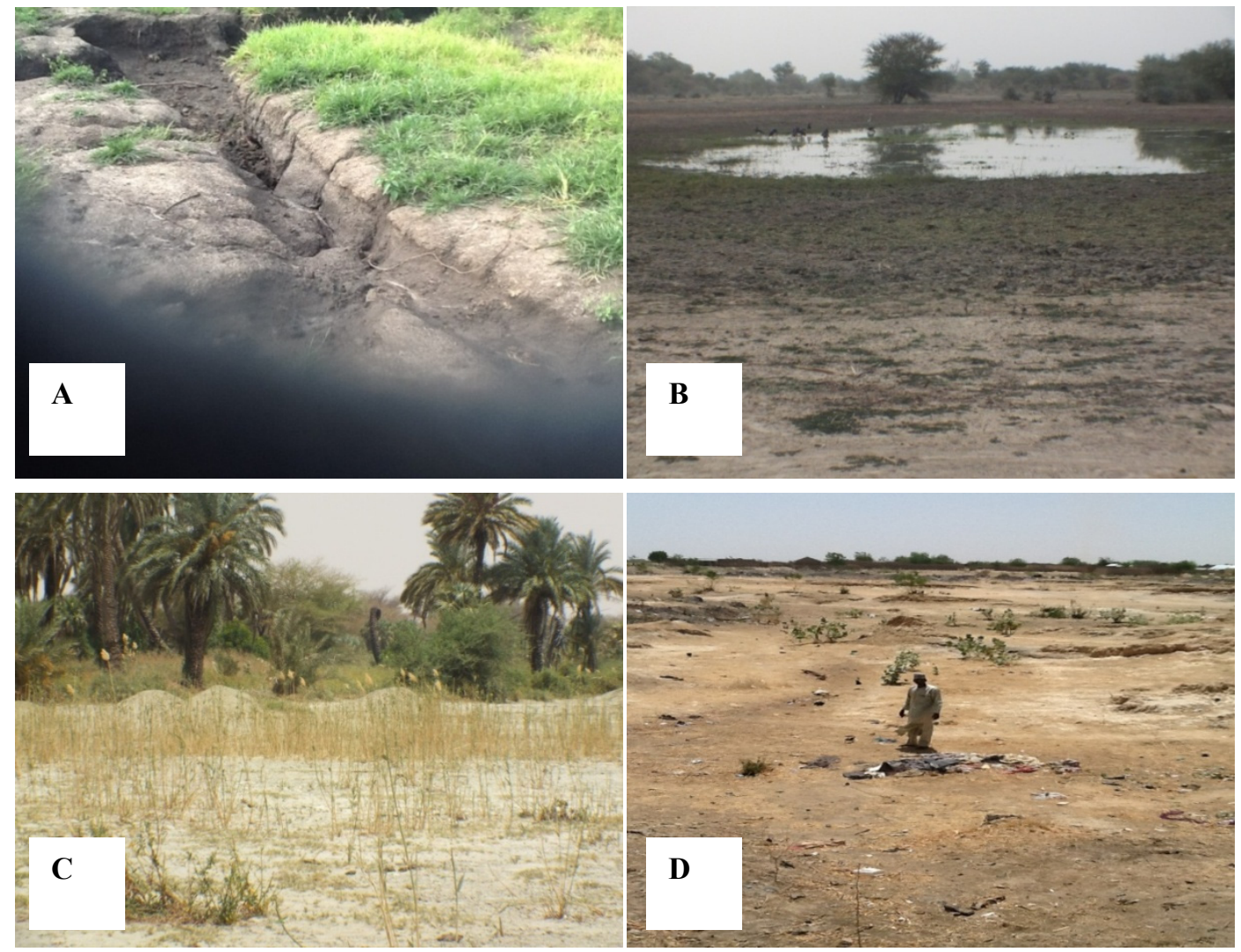

Figure 8. Some typical micro structures of the basin (A) Gully formed from an enlarged rill. (B) A pond formed from buckled rills that have coalesced. (C) Linear moulds forming a ridge. (D) Deflation basin (blowout) that have been enlarged

Deflation basins are wide spread in areas further from streams. They are generally 20 to $30 \mathrm{~m}$ in circumference are usually devoid of vegetation cover. Also, another prominent landform in the northwestern and northeastern fringes of the basin is the wide occurrences of closed depressions (topographic basins) which display a bewildering degree of variability in morphological expression. These features also described as pans and playas (Goudie, 1991) have been ascribed to a variety of morphogenic processes that set their origin. This morphogenic processes range from simple desiccation cracks or depressions filled by seasonal rainfall, tectonic subsidence and aeolian deflation. These depressions have been of great importance to the human population from prehistoric times to the present day as source of water and minerals in the area.

Narrow ridges of up to $9 \mathrm{~m}$ in height (Figure 9A) and somewhat similar in geomorphic expression to the Yardangs described by Livingstone and Warren (1996) are prominent land forms around Bullura, Binduldul and Kesa Ngala of Borno State located in the northeastern part of the basin. Another major landform of the basin is 
the wide occurrences of sand dunes of different sizes, morphologies and orientations. The eastern part of the basin consists of mainly stable barchanoid sand dunes aligned to the NNE-SSW direction. These sand dunes form a regular long parallel pattern of up to $21 \mathrm{~km}$ broke only by small discontinuities (Figure 9B \&C).

The northwestern, central and towards the Lake Chad part of the basin, the sand dunes are shorter in height (less than $6 \mathrm{~m}$ ), and they become less conspicuous in the west eastern part of the basin (Figure 9D). In these areas, the depressions between the dunes are covered by lagoonal and deltaic deposits. Also further north of the basin, the occurrences of sand islands in between the less well-developed sand dunes are prominent (Figure 9E). The orientation of the dunes in these areas is irregular and merges with the sand islands which are submerged in most areas by the black cotton soil locally known as "Firgi". The areas covered by the black soil forms extensive flat plains that are highly dissected by a variety of streams most of which are dry and partially filled with aeolian deposits for the greater part of the year. Also, a variety of current and fossil fluvial land forms such as lavees and poin bars, barchans and meanders, spill plains, back swamp valleys and smaller depressions most of which had been greatly altered by wind action also abound these areas. The inert-dunes depressions whose floors are mostly up to $10-15 \mathrm{~m}$ lower host a wide range of Oasis forming alkaline lakes (Figure 9F \&G). These Oases are in hydraulic contact with the phreatic aquifer seeping out of the surrounding dunes. The level of water in these Oases responds to the high evaporation rate during the long dry season drying up and their floor forming evaporates such as trauna $\left(\mathrm{KCl}_{2}\right)$ and associated minerals (Figure $9 \mathrm{H}$ ).
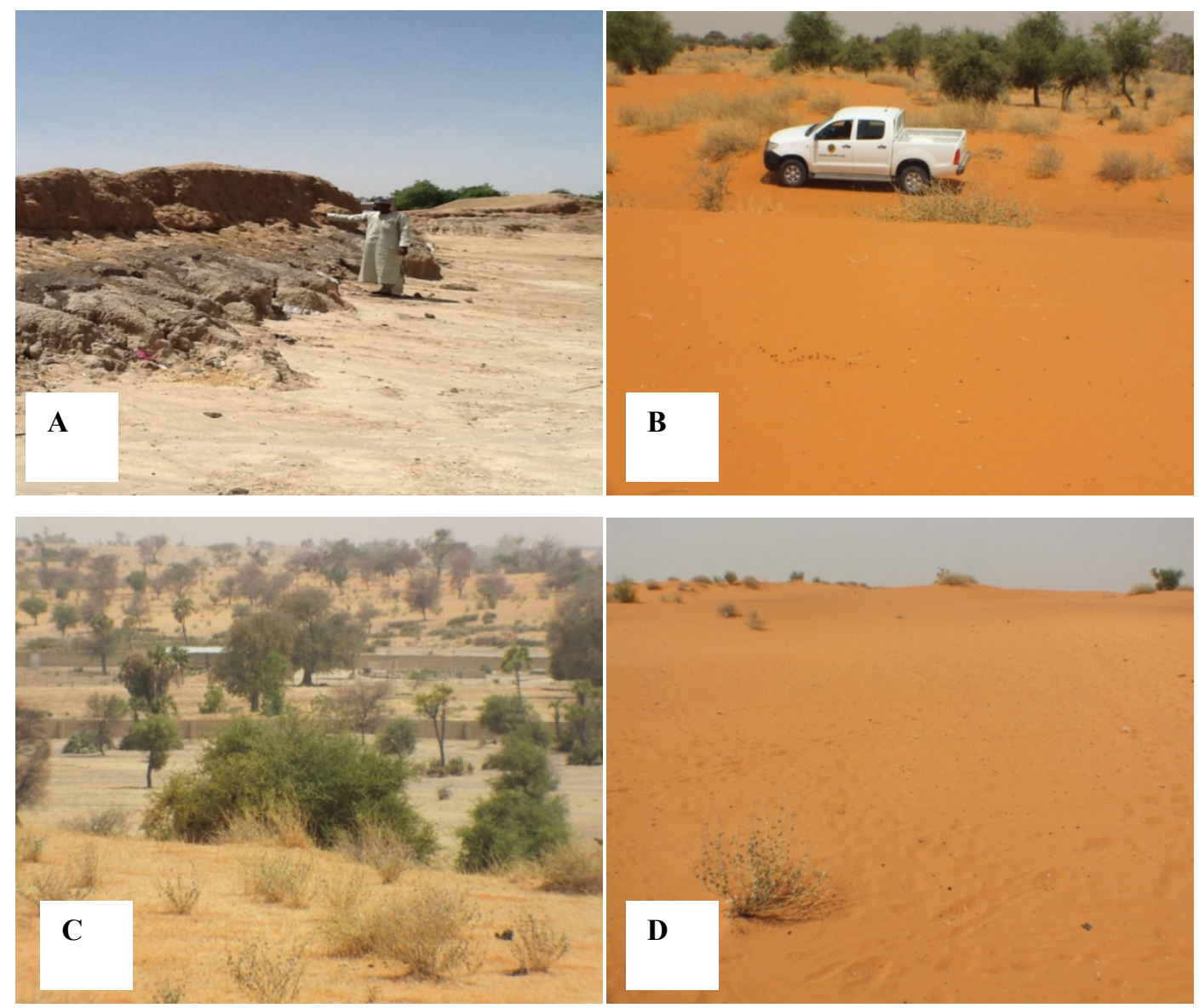

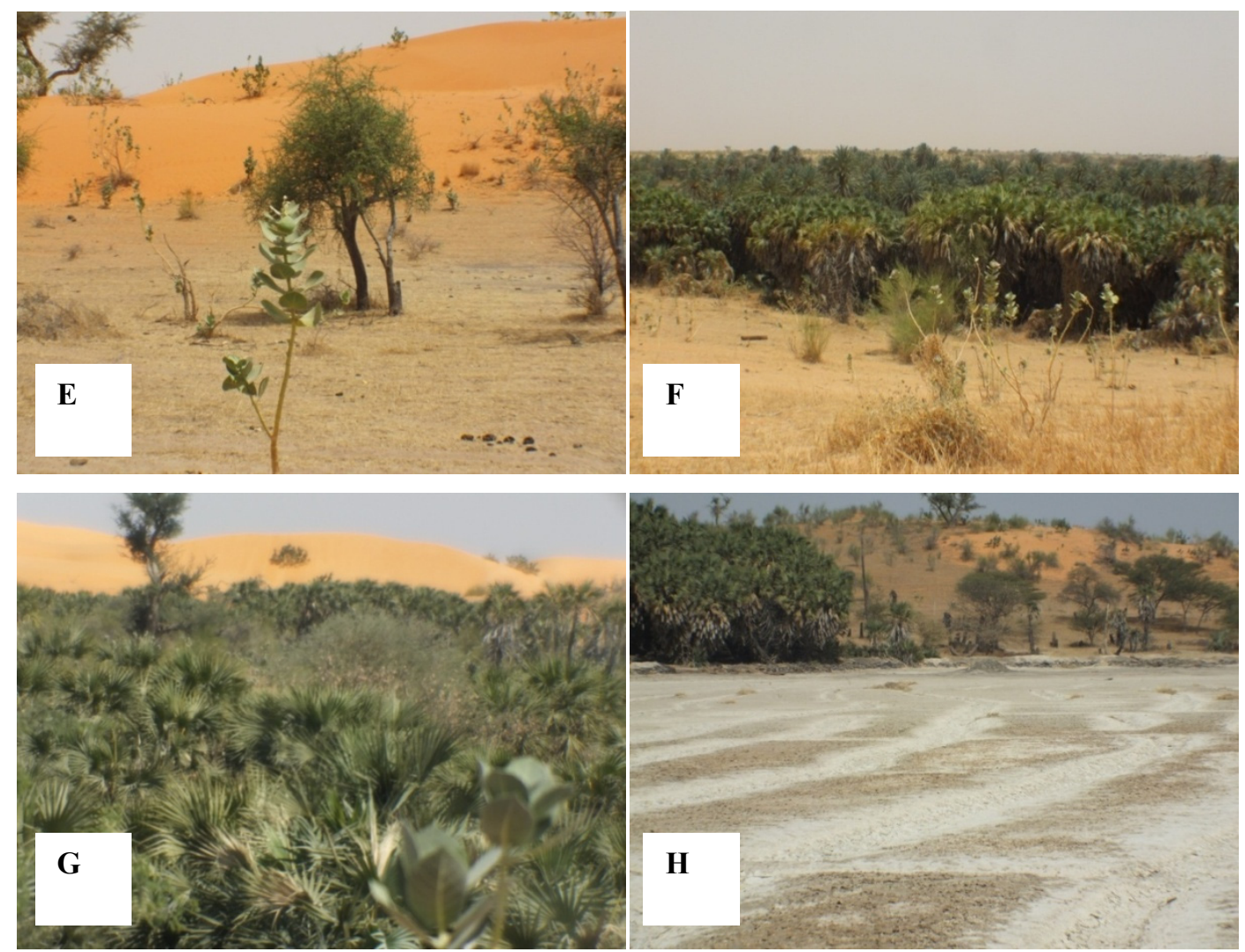

Figure 9. (A) A view of Yadang at Bullura in northern Borno State. (B) \& (C) is a general view of sand dune landscape in the central part of the basin. (D) A typical less developed sand dune in the NE part of the basin. (E) Is a view of a sand dune that has merged with Sand Island ( $F \& G)$ Oasis formed between dune floors covered with grasses and shrubs while $(\mathrm{H})$ View of the Oasis floor after dying and forming an evaporate mineral

\section{Conclusion}

The Nigerian sector of the Chad Basin locally known as the Bornu Basin is the largest of the Nigerian's inland basins. With the renewed vigor by government in the search for oil and gas in the basin, geomorphometric and terrain analysis of the area provides an exact and measurable picture of the relief form and landforms which are essential in many aspects of prospecting and exploitation of such resource. The application of the techniques of GIS, remote sensing and field investigations in this research over the use of conventional maps and methods such as the manual interpretation of topographic maps and aerial photographs generated in the 1970's have provided reliable data devoid of spatial ambiguity. The generated maps can be easily stored, quarried and edited as desired. This is important considering the spatial and temporal dynamics involved in the processes of oil and gas exploration and exploitation. However, this research covered just some few aspects of the morphology and morphodynamics of the basin. Further research is recommended encompassing all factors of the morphology and morphodynamics especially environmental factors such as climate, human and geological factors. When this is achieved, quality baseline data will be generated upon which exploration and exploitation of the resource could be based upon. Environmental degradation and associated problems that occurred in the Niger-Delta and other basins of the country will be avoided through sustainable utilization of the terrain.

\section{Conflict of interests}

The authors declare that there is no conflict of interests regarding the publication of this paper.

\section{Reference}

Avbovbo, A. A., Ayoola, E. O., \& Osahon, G. A. (1986). Depositional Styles in Chad Basin of Northeastern Nigeria. Association of American Petroleum Geologist Bulletin, 70, 1787-1798

Belnap, J., Munson, M. S., \& Field, P. J. (2011). Aeolian and Fluvial Processes in Dry land Regions: The Need for Integrated Studies. Hydrecology, 4, 615-622. 
Carter, J. D., Barber, W., Tait, E. A., \& Jones, G. P. (1963). The Geology of Parts of Adamawa, Bauchi and Borno Provinces in Northern Nigeria, Geological Survey of Nigeria. Bulletin, 30, 99.

Cooke, R. U., \& Warren, A. (1973). Geomorphology in Deserts. Batsford, London.

Dorathy, B. U., Etim, D. U., \& Inyenomie, T. (2018). Near-Surface Siesmic Characteristics in Bornu-Chad Basin, Nigeria. Asian Journal of Applied Science and Technology, 2(3), 83-93

Durrand, A. (1982). Oscillations of the Lake Chad over the past 50,000 years, new data and hypothesis. Paleoclimatology, 39, 37-53

Furon, R. (1963). The Geology of Africa (pp. 337). Oliver and Boyld, London

Gaudie, A. S. (1991). Pans, Progress in Physical Geography, 15, 221-237.

Grove, A. T. (1959). A Note on the Former Extent of the Lake Chad. Geographical Journal, 125, 465-467.

Janet, E. N. (1991). The Extent of Sand Dunes in Northern Nigeria as shown by Image enhancement. The Geographical Journal, 157, 13-24.

King, L. C. (1967). The Morphology of the Earth (2nd ed.). Edingburg.

Less, D. J. (1982). The Sand Dunes of Gover as potential Indicators of Climatic Change in Historical Time (Vol. 9, pp. 25-35). Cambria.

Nichol, E. J. (1991). The Extent of Desert Dunes in Northern Nigeria as shown by Image Enhancement. The Geographical Journal, 157(1), 13-24.

Nyanganji, J. K. (2002). The Morphology and Hydrography of the Ngadda Catchment and Bama Beach Ridge. Frankford am main, 89-90.

Obaje, N. G. (2009). The Bornu Basin (Nigerian Sector of the Chad Basin) In: Geology and Mineral Resources of Nigeria, Lecture Notes in Earth Sciences (Vol 120). Springer.

Ofomata, G. E. K. (2009). Basic Geomorphology for Africa. Enugu, Jamoe publishers.

Ostaficzuk, S. (1985). The Impact of Geology on the Varnishing Waters of the Rivers of Maiduguri. Paper Presented at the International Conference on Arid Zone Hydrology and Water Resources, CATZ University of Maiduguri.

Oteze, G. E., \& Tamajong, S. C. (1987). Drought and Lake Chad Basin Presented at the Lake Chad Commission's International Seminar on: Water Resources in the Lake Chad Basin. Management and Conservation, N'djamena, Tchad.

Pan, F., Liao, J., Li, X., \& Guo, H. (2013). Application of the Inundation Area-Lake Level Rating Curves Constructed from the SRTM DEM to Retrieving Lake Levels from Satellite Measure Dinundation areas. Computers and Geosciences, 52, 168-179.

Pereta, K., \& Pereta, K. (2015). Geomorphological Interpretation Through Satellite Imagery and Dem Data. American Journal of Geophysics, Geochemistry and Geosystems, 2, 19-36.

Peters, S. W., \& Ekweozor, C. M. (1982). Petroleum Geology of Benue Trough and Southern Chad Basin, Nigeria. Association of American Petroleum Geologist Bulletin, 66, 1141-1149.

Pour, B. A., \& Hassim, M. (2015). Regional Geological Mapping in Tropical Environments Using LANDSAT TM and SRTM Remote Sensing Data. Annals of the Photogrametry, Remote Sensing and Spatial Information Sciences (Vol. II-2/W2). Joint International Geoinformation Conference, Kuala Lampur, Malaysia.

Samaila, N., Abubakar, M., Dike, E., \& Obaje, N. (2006). Description of Soft-Sediment Deformation Structures in the Cretaceous Bima Sandstone from the Yola Arm, Upper Benue Trough, Northeastern Nigeria. Journal of African Earth Sciences, 44(1), 66-74

Servan-Valdary, S. (1980). In M. A. J. Williams \& A. Fuure (Eds.), L'environment Quaternary Du Bassin du Tchad (pp. 133-162). A. A. Balkema

Shettima, B. F. D., \& Adams, M. V. J. (2017). Mineralogy and Geochemistry of Mudstones of the Bama Ridge (Upper Chad Formation) Bornu basin, North-eastern Nigeria. International Research Journal of Advanced Engineering and Science, 153-159.

Theimeyer, H. (1991). A New 14C Record from the Bama Ridge Near Konduga, Borno State, NE Nigeria. Annals of Borno 8/9 University of Maiduguri, Maiduguri. 
Visser, S. M., Sterk, G., \& Ribolzi, O. (2004). Techniques for Simultaneous Quantification of Wind and Water Erosion in Semi-arid Regions. Journal of Arid Environments, 59, 699-717.

Warren, A. (1976). Dune Trend and the Ekman Spiral. Nature, 259, 653-654.

Zarma, A. A., Samaila, N. K., Abubakar, M. B., \& Ahmed, S. B (2015). Pebble Morphometric Analysis and Environmental Diagnosis: A case study of the Bama Ridge, Borno Sub-basin-Nigeria. Annals of Borno, $147-160$.

\section{Copyrights}

Copyright for this article is retained by the author(s), with first publication rights granted to the journal.

This is an open-access article distributed under the terms and conditions of the Creative Commons Attribution license (http://creativecommons.org/licenses/by/4.0/). 